\title{
ANALYSIS OF TRAFFIC ACCIDENTS IN THE DISTRICT GRESIK \\ (Case Study: Road Duduksampeyan Sta km $16+000$ - Sta km $16+500)$
}

\author{
Debi Fariska \\ Faculty of Engineering, Narotama University Surabaya \\ farisengineer10@gmail.com \\ Sri Wiwoho Mudjanarko \\ Faculty of Engineering, Narotama University Surabaya
}

\begin{abstract}
Traffic accident is an accident that occurs unexpectedly and unintentionally involving a vehicle which resulted in casualties and material damage. The problem of traffic accidents on the road Duduksampeyan Sta $\mathrm{km} 16+000$ - Sta km $16+500$ is the most significant. The purpose of this study was conducted to determine the level of traffic accidents that occurred in 2013-2018. This study uses a method that refers to the calculation of the number of accidents. The observations in the field of road safety facilities are still inadequate, lighting is in only one side of the road as much as \pm 10 pieces, and the absence of traffic signs (speed limits, accident-prone areas, etc.). The volume of daily traffic averages on these roads as much as 3833 veh / hour. The results of the analysis carried accident rate by 158 the highest annual accident / $\mathrm{km}$ occurred in 2018. Meanwhile, based on the fatality index, it was 47.76\%, the highest in 2013.
\end{abstract}

Keywords : Road safety facilities, daily traffic volume on average, the rate of accidents

\section{INTRODUCTION}

Duduksampeyan road is a road that connects between Gresik to Lamongan. The road is the main access for traffic events beyond Gresik society who want to work. Various types of vehicles passing through the road Duduksampeyan to perform everyday activities. More and more vehicles on the road, the possibility of more traffic accidents occur. Traffic accidents are accidents that occur unexpectedly and unintentionally engage the vehicle, resulting in casualties and material damage.

The rate of accidents in the district of Gresik is still quite high. Besides causing minor injuries, serious injuries or death, the accident also resulted in material loss is large enough. Gresik recorded Traffic Police, traffic accidents have occurred as many as 596 events in the streets of Gresik throughout 2017. The number of victims who died in the accident on various roads in Gresik many as 175 people, 5 people were seriously injured, and 709 people suffered minor injuries. One highway in Gresik which become prone to accidents is on Highway Duduksampeyan. In addition, accidents also occur in the Kingdom Cerme, Driyorejo Raya, Raya Manyar and Mayjend Sungkono Road. Hundreds of times the event occurrence of traffic accidents during 2017 has led to loss of life and material losses of approximately USD 1.3 billion. Therefore the riders are expected to be more cautious and obey traffic rules, particularly in dots skeleton track.

Given that the effects resulting from the accident that many victims suffered minor injuries as well as severe and even death as well as material losses were large enough, then the urgent need to reduce the traffic accidents. The development of infrastructure and other traffic facilities are well done to avoid the problem of traffic accidents. 


\section{Study of literature}

Traffic has several important components therein which include humans, vehicles, roads, and regulations. Of the four components can be understood in view of various phenomena that occur in traffic such as:

a. to examine how the accident occurred and traffic component is causing the most dominant accident occurred.

b. can prioritize traffic components which must be prioritized in order to improve the performance of transport.

c. can assess the performance improvement of transport leading to failure and to ensure that does not happen again.

Traffic accidents can occur due to several factors that influence. Factors that cause traffic accidents there are three, namely:

1) the human factor is still a lot going for driving over the speed limit, less alert / guard, and do not obey traffic rules.

2) vehicle factors that are not driven properly and the condition of the vehicle unfit to drive will result in an accident.

3) factor of damaged roads and potholes and environmental conditions unfavorable weather caused by air pollution and foggy weather will deter motorists visibility which resulted in the accident.

Type of traffic accidents is divided into 4 are as follows:

4) accident minor injuries where the condition of the victim suffered only minor injuries.

5) seriously injured accident victims where the condition of permanent disability.

6) fatal accidents where the condition of the victim to death.

7) crash position in which the accident occurred on the position of the collision from the front, side, rear or lost control while driving.

Heterogeneous traffic conditions and the increasing number of vehicle volume resulted in a bottleneck both congestion and traffic accidents. The need for a traffic control device in order to resolve or regulate traffic flow conditions that occur. Traffic-control devices, among others such as road markings, traffic signs and traffic lights.

The calculation of the number of accidents was conducted to determine the level of traffic accidents that occur. Several methods can be used for the calculation include:

1. Severity Index (SI)

Severity Index is a fatality index or severity of accidents that illustrates the relative levels of violence and is defined as the number of fatalities per accident. Can be expressed in percent and is formulated as follows:

$\mathrm{SI}=(\mathrm{F} / \mathrm{A}) \times 100$

Information :

SI $\quad=$ Fatality index (\%)

$\mathrm{F}=$ The number of fatal accidents (fatal accidents per year)

$A=$ Number total accidents on the roads (total accidents per year)

2. Accident Rate per mile

Accident rate per-mile is the number of accidents per mile than a certain roads. Dangerous accident is expressed as the number of accidents of all types per-mile from any road. For cases in Indonesia is illustrated perkm of roads were reviewed, formulated:

$R=A / L$

Information :

$\mathrm{R}=$ Score accidents $/ \mathrm{km} /$ year

$A=$ Number of accidents during the observation period (accident / year)

$L=$ The volume of vehicles during the observation period (vehicle-km) 


\section{METHODOLOGY}

This study uses a method that refers to the calculation of the number of accidents. Methods of data collection is done by collecting primary data obtained from direct observation of road safety facilities and daily traffic average at the study site. The collection of secondary data, the traffic accident from years 2013 - 2018 were obtained from the Traffic Police Gresik. These data are then processed for analysis using a predetermined method.

Location of the study was conducted at the highest accident-prone areas in road Duduksampeyan Sta km $16+000$ - Sta km $16+500$. These observations were made in order to obtain a detailed picture of the condition of existing safety facilities and the daily traffic volume. This information is conducted to support the analysis of data that have been obtained.

\section{RESULTS AND DISCUSSION}

Based on primary data and secondary data already collected. Furthermore, the data is processed in order to obtain valid results to be presented based on the analysis performed. The results of data analysis, among other facilities such as a review of road safety, traffic accidents, and the daily traffic volume on average.

\section{review of the Road Safety Facility}

Based on the results of the field observations made regarding road safety facilities on road sections location area Duduksampeyan sta $\mathrm{km} 16+000$ - sta $\mathrm{km} 16+500$ found that street lighting is in only one side of the road as much as 10 lights along the road. There is a warning light (Warning Light) at the junction of the road to Jl. Duduksampeyan market but not lit and does not function properly. Road markings along the road most need repainted and also the zebra crossing to be clearly visible to road users. The absence of traffic signs (accident-prone areas, the speed limit, the location of a U-turn, etc.). There is a traffic monitoring post of Police Duduksampeyan as a police duty to regulate traffic on the road

\section{The level of Traffic Accidents}

Analysis of the level of traffic accidents is done using two ways of calculation which is based on the incidents with the calculation formula Accident Rate per mile and based fatality accident victims with the calculation formula Severity Index (SI).

\section{Based on Genesis Crash}

Based on data obtained from the Traffic Police Gresik from years 2013 - 2018 according to the amount of the incidence of road accidents that occurred in Duduksampeyan Sta km $16+000-$ Sta km $16+500$.

Table 1.Total Events Accidents

\begin{tabular}{cccc}
\hline No. & Year & $\begin{array}{c}\text { Number of Traffic } \\
\text { Accidents Genesis / } \\
\text { Year }\end{array}$ & percentage\% \\
\hline 1 & 2013 & 67 & $17 \%$ \\
2 & 2014 & 64 & $16 \%$ \\
3 & 2015 & 63 & $16 \%$ \\
4 & 2016 & 56 & $14 \%$ \\
5 & 2017 & 63 & $16 \%$ \\
6 & 2018 & 79 & $20 \%$ \\
total & 392 & $100 \%$ \\
\hline
\end{tabular}

Based on data from the total number of accidents can know the level of accidents that occur from year 2013 - 2018 was calculated as follows 


$$
R=\frac{A}{L}
$$

Information :

$\mathrm{R}=$ Score accidents $/ \mathrm{km} /$ year

$A=$ Number of accidents during the observation period (accident / year)

$\mathrm{L}=$ The volume of vehicles during the observation period (vehicle-km)

The calculation results :

Example 2018

$R=\frac{A}{L}$

$R=\frac{79}{0.5}=158$ accident per year $/ \mathrm{km}$

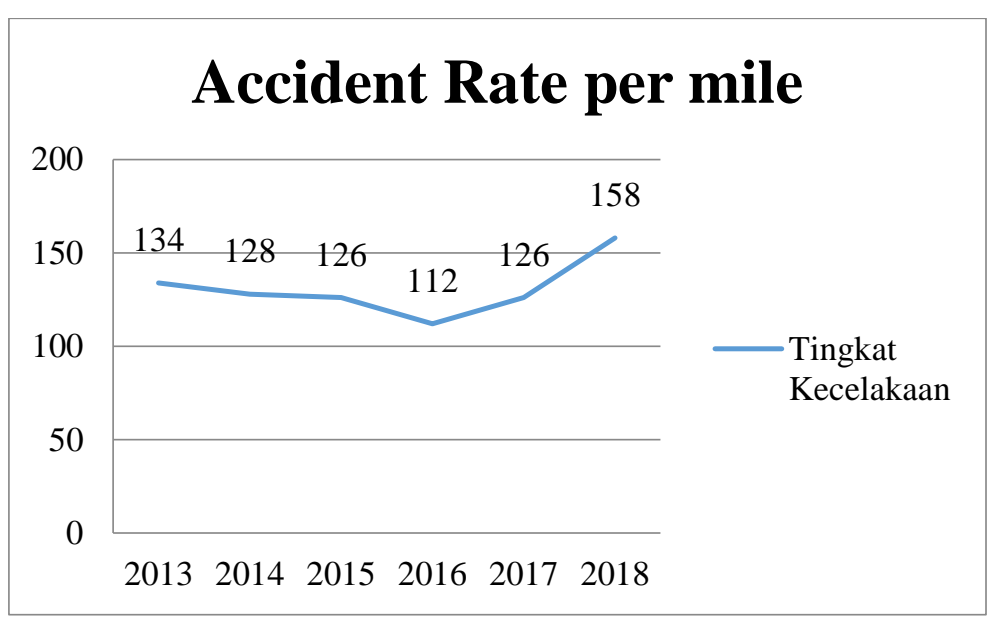

Picture 1. Accident incidence rate chart Per Mile

1. Based on fatality victim

Based on data obtained from the Traffic Police Gresik from years 2013 - 2018 according to the number of casualties occurred in road Duduksampeyan Sta km $16+000-$ sta km $16+500$.

Table 2. Number of Casualties

\begin{tabular}{cccccc}
\hline No. & Year & Die & $\begin{array}{c}\text { serious } \\
\text { wound }\end{array}$ & $\begin{array}{c}\text { Minor } \\
\text { injuries }\end{array}$ & $\begin{array}{c}\text { Total } \\
\text { Victim / } \\
\text { Year }\end{array}$ \\
\hline 1 & 2013 & 32 & 0 & 69 & 101 \\
2 & 2014 & 29 & 1 & 74 & 104 \\
3 & 2015 & 28 & 4 & 71 & 103 \\
4 & 2016 & 17 & 0 & 64 & 81 \\
5 & 2017 & 21 & 1 & 74 & 96 \\
6 & 2018 & 30 & 6 & 82 & 118 \\
\multicolumn{2}{c}{ total } & 157 & 12 & 434 & 603 \\
percentage\% & $26.04 \%$ & $1.99 \%$ & $71.97 \%$ & $100.00 \%$ \\
\hline
\end{tabular}

Based on data of the number of accident victims can know the level of accidents that occur from year 2013 - 2018 was calculated as follows:

$$
S I=\frac{F}{A} \times 100 \%
$$


Information :

$\mathrm{SI} \quad=$ Fatality index (\%)

$\mathrm{F}=$ Number of Fatal Accident (fatal accidents per year)

$A=$ The total number of accidents on the roads (total accidents per year)

The calculation results :

Examples of the Year 2013

$$
S I=\frac{F}{A} \times 100 \%
$$

$S I=\frac{32}{67} \times 100 \%=47.76 \%$ fatality index

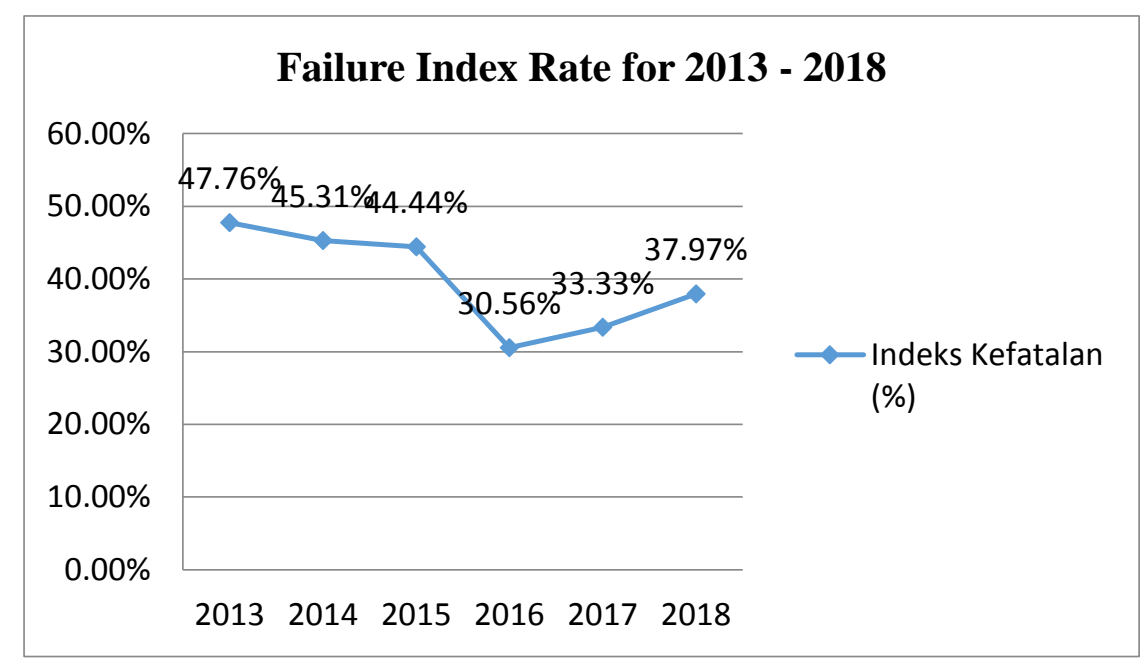

Figure 2. The level of fatality index chart Year $2013-2018$

\section{Daily Traffic Volume Average}

Analysis of traffic average traffic conducted to determine the hourly, daily, monthly, and yearly and is used for accident analysis (linking the number and types of vehicles on traffic flow. The method used in this research is by using traffic flow counting method (Traffic Counting). The steps of sampling are:

a. Record all types of vehicles that pass from each direction.

b. Vehicles are recorded in intervals of 60 minutes

Sampling was carried out for 3 days with details of two days of work and one day off in the morning, afternoon, and evening. Sampling was carried out with the help of four people who are ready at different observation points. Observations carried out by 2 people watching on the road right and 2 on the left. 
Table 3. Data Number of Vehicles

\begin{tabular}{cccccc}
\hline No. & Transportation & \multicolumn{5}{c}{ Time } \\
& type & $7: 00$ to & $12: 00$ to & $16: 00$ to & total \\
& & $08: 00$ & $13: 00$ & $17: 00$ & \\
\hline 1 & Car & 760 & 579 & 886 & 2225 \\
2 & truck & 409 & 324 & 294 & 1027 \\
3 & pick Up & 170 & 166 & 184 & 520 \\
4 & pedicab & 0 & 0 & 0 & 0 \\
5 & Motorcycle & 3218 & 1896 & 3246 & 8360 \\
6 & Bike & 1 & 1 & 2 & 4 \\
7 & Public & 11 & 10 & 0 & 21 \\
8 & transportation & 11 & 36 & 54 & 134 \\
& Bus & 44 & & 12291 \\
\hline
\end{tabular}

Table 4. Data Number of Vehicles

\begin{tabular}{cccccc}
\hline No. & $\begin{array}{c}\text { Transportation } \\
\text { type }\end{array}$ & $\begin{array}{c}\text { Time } \\
\text { (2:00 to }\end{array}$ & $\begin{array}{c}12: 00 \text { to } \\
16: 00 \text { to }\end{array}$ & total \\
& & $08: 00$ & $13: 00$ & $17: 00$ & \\
\hline 1 & Car & 682 & 577 & 878 & 2137 \\
2 & truck & 405 & 251 & 364 & 1020 \\
3 & pick Up & 166 & 192 & 171 & 529 \\
4 & pedicab & 0 & 0 & 0 & 0 \\
5 & Motorcycle & 3201 & 1686 & 3479 & 8366 \\
6 & Bike & 0 & 2 & 1 & 3 \\
7 & Public & & & & \\
7 & transportation & 10 & 9 & 0 & 19 \\
8 & Bus & 42 & 30 & 59 & 131 \\
& & Total Vehicles In 3 Hours & & 12205 \\
\hline
\end{tabular}

Table 5. Data Number of Vehicles

\begin{tabular}{cccccc}
\hline No. & $\begin{array}{c}\text { Transportation } \\
\text { type }\end{array}$ & $\begin{array}{c}\text { Time } \\
\text { 7:00 to }\end{array}$ & $\begin{array}{c}12: 00 \text { to } \\
16: 00 \text { to }\end{array}$ & total \\
& & $08: 00$ & $13: 00$ & $17: 00$ & \\
\hline 1 & Car & 651 & 531 & 711 & 1893 \\
2 & truck & 302 & 285 & 318 & 905 \\
3 & pick Up & 151 & 152 & 170 & 473 \\
4 & pedicab & 0 & 0 & 0 & 0 \\
5 & Motorcycle & 2098 & 1844 & 2664 & 6606 \\
6 & Bike & 1 & 3 & 0 & 4 \\
7 & Public & & & & \\
8 & transportation & 8 & 5 & 0 & 13 \\
& Bus & 37 & 26 & 48 & 111 \\
& & Total Vehicles In 3 Hours & & 10005 \\
\hline
\end{tabular}


From the results of the three data will be added together to determine the daily traffic average calculated as follows:

$$
\begin{gathered}
\text { LHR }=\frac{\text { Amount of Traffic During Observation }}{\text { Time Observation }} \\
\text { LHR }=\frac{(12291+12205+10005) \text { vehicle }}{9 \text { hour }} \\
\text { LHR }=\frac{(34501) \text { vehicle }}{9 \text { hour }}=3833.4 \text { rounded up to } 3833 \text { vehicles per hour }
\end{gathered}
$$

Thus, the volume of daily traffic average in road Duduksampeyan sta km $16+000$-sta $\mathrm{km} 16+500$ as many as 3833 vehicles per hour.

\section{CONCLUSION}

Based on the discussions can be concluded as follows:

1. Road safety facilities are still inadequate as the lack of traffic signs (accident-prone areas, speed limits, signs for location-turn instructions, etc.) that street lighting is in only one side of the road as much as \pm 10 lights.

2. The accident rate based on the number of events occurred in the year 2018 as many as 158 accidents per year / $\mathrm{km}$, while the accident rate index based on the highest fatality occurred in 2013 amounted to $47.76 \%$.

3. The volume of daily traffic average on the road section based on the observations and calculations carried out as many as 3833 vehicles per hour with vehicles that dominate the motorcycle manifold.

\section{REFERENCES}

Andi, S. (2017).600 LebihKecelakaanLaluLintas Terjadi Di Gresik Selama 2017.http://beritagresik.com/news/peristiwa/27/12/2017/600-lebih-kecelakaan-lalu-lintasterjadi-di-gresik-selama-2017. html, diaksespadatanggal 25 Oktober 2018.

Fajrizal. (2014). Analisis Tingkat Kecelakaan Lalu Lintas (Studi Kasus: Ruas Jalan Meulaboh - Samatiga Sta 8+000 - Sta 8+300). Universitas Teuku Umar.

Hairudin. (2013). Studi Daerah Rawan Kecelakaan (DRK) Ruas Jalan Sungai Pinyuh-Sidas Provinsi Kalimantan Barat. Jurnal Mahasiswa Teknik Sipil Universitas Tanjungpura.

Haris, I. V. (2012). Kajian Daerah Rawan Kecelakaan Lalu Lintas Di Jalan Kolektor Primer Wilayah Gresik Bagian Selatan Tahun 2012. Universitas Negeri Surabaya.

Manuho, J. A. (2016). Perhitungan Lalu Lintas Harian Rata-Rata Pada Ruas Jalan Tumpaan-Lopana. Politeknik Negeri Manado.

Risdiyanto. (2014). Rekayasa \& manajemen lalu lintas. Yogyakarta: LeutikaPrio.

Supriyatno, D., Mudjanarko, S. W., \& Utomo, W. M. (2018). Velocity Maximum Speed Analysis On Blackspot Area In Basuki Rachmad Krian - Balongbendo Sidoarjo, Indonesia. International Journal of Engineering \& Technology. 